\title{
B220 expression as an immunological marker for differentiation of Feline Leukemia Virus carrying cats
}

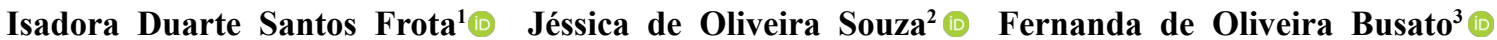 \\ Cristina Abreu de Araujo ${ }^{2}$ (i) Flávio Curbani ${ }^{4,5}$ (i) David Olivieri ${ }^{6}$ (i) Carlos Eduardo Tadokoro Ta, $^{1,2,4^{*}}$ (i)
}

${ }^{1}$ Programa de Pós-graduação em Ciência Animal (PPGCA), Universidade Vila Velha (UVV), Vila Velha, ES, Brasil.

${ }^{2}$ Programa de Pós-graduação em Ciências Farmacêuticas (PPGCF), Universidade Vila Velha (UVV), Vila Velha, ES, Brasil.

${ }^{3}$ Laboratório de Imunobiologia, Universidade Vila Velha (UVV), Vila Velha, ES, Brasil.

${ }^{4}$ Programa de Pós-graduação em Ecologia de Ecossistemas (PPGEE), Universidade Vila Velha (UVV), 29102-623, Vila Velha, ES, Brasil. E-mail: carlos.tadokoro@uvv.br. "Corresponding author.

${ }^{5}$ Departamento de Tecnologia Industrial, Universidade Federal do Espírito Santo (UFES), Vitória, ES, Brasil.

${ }^{6}$ Escuela Superior de Ingeniería Informatica, Universidade de Vigo, Spain.

ABSTRACT: Feline leukemia virus (FeLV) causes an infection in cats that, in some cases, can also be reported with other pathologies, such as infection with feline immunodeficiency virus (FIV), feline infectious peritonitis (FIP), and lymphoma. Although, a compromised immune response is reported in these animals, little is known about the immunological state of their cells. To shed some light in this area, we studied peripheral blood samples from both infected and non-infected cats with FeLV, with or without FIV, FIP, and lymphoma. We tested a panel of monoclonal antibodies $(n=11)$ against mouse and human antigens and we reported that cat leukocytes can be stained with anti-mouse B220 monoclonal antibody; therefore, percentages of B cells were evaluated in different cat groups. Our results showed that cats with FeLV and FIP, or with leukemia, presented a large decrease in B220+ mononuclear cells. However, FeLV+ cats without clinical signs, or with unspecific clinical signs, had the same amount of B220+ mononuclear cells as healthy cats (control cats). Since the expression of B220 is exclusively restricted to the naïve $B$ cell population, we inferred that the absence of these $B$ cells in FeLV+cats is related to other conditions that affect $B$ cell numbers, such as viral infections and leukemias. Therefore, the amount of naïve B cells in peripheral blood (i.e., B220+ cells) can be used to identify FeLV + cats concomitantly carrying FIP or leukemia, from FeLV+ cats with lymphoma or without any clinical signs.

Key words: B cells, FeLV, FIV, FIP, lymphoma.

A expressão de B220 como um marcador imunológico para diferenciação de gatos portadores do vírus da Leucemia Felina

RESUMO: $O$ vírus da leucemia felina (FeLV) causa de uma infecção em gatos, que também podem ter outras patologias, como a imunodeficiência felina (FIV), a peritonite infecciosa felina (FIP) e linfoma. Embora uma resposta imune comprometida seja encontrada nestes animais, pouco se sabe sobre o estado imunológico de suas células. Para ampliar o número de testes com a finalidade de avaliar o estado imunológico destes animais, estudamos amostras de sangue periférico de gatos infectados, ou não, com FeLV, e que apresentavam (concomitantemente) FIV, FIP e linfoma. Para isto, amostras de sangue foram marcadas com um painel de anticorpos monoclonais contra antígenos de camundongos e humanos $(n=11)$, para avaliar seu potencial para estudos imunológicos em gatos. De todo o painel de anticorpos testados, apenas o anticorpo anti-B220 de camundongo foi capaz de marcar leucócitos de gato. Nossos resultados mostraram que os gatos com FeLV e FIP, ou com leucemia, apresentaram uma grande diminuição nas células mononucleares B220+. No entanto, gatos FeLV+ sem sinais clínicos, ou com sinais clinicos inespecificos, tiveram a mesma quantidade de células B220+ que os gatos saudáveis (gatos controle). Como a expressão de B220 é restrita à população de células B nä̈ve, podemos inferir que a ausência dessas células B em gatos FeLV+ está relacionada a outras condições que afetam o número destas células, como infecções virais e leucemias. Portanto, a quantidade de células $B$ naïve no sangue periférico pode ser usada para identificar gatos FeLV+ concomitantemente portadores de PIF ou leucemia, de gatos FeLV+ com linfoma ou sem sinais clínicos.

Palavras-chave: células $B, F e L V, F I V$, FIP, linfoma.

Feline leukemia virus (FeLV) affects domestic cats and is also reported in some wild cat species, with no gender preferences (BANDECCHI et al., 2006; MAKUNDI et al., 2017; HARDY JR. et al., 1976). There are large variations in FeLV prevalence within and across different countries. In Brazil, there are differing prevalence across regions, from 5.3 to $47.5 \%$ (FIGUEIREDO and ARAÚJO 
JÚNIOR, 2011), sometimes with high lymphoma association (CRISTO et al., 2019), while in other countries these indexes are low, e.g., 5.6\% in the USA (BURLING et al., 2017; SHAHRANI et al., 2011; STAVISKY et al., 2017). However, in endemic areas, transmission rates can reach nearly $30 \%$ by vertical or horizontal transmissions (HARDY JR. et al., 1976) The most common method for detecting FeLV is an ELISA for p27 antigen (LEVY et al., 2017), and the most efficient disease control measurements is immunization of FeLV-negative cats and isolation of FeLV-positive cats (BURLING et al., 2017; GROSENBAUGH et al., 2017).

An important factor in disease outcome is the cat immune response. It is assumed that some cats efficiently suppress the onset of infection, either by completely deleting the first infected cells (no viremia), or by establishing a protective immunity after a period of positive viremia (virus carriers for the rest of their lives). It is also possible that FeLV+ animals can become viremia-negative, with no signs of disease (TORRESA et al., 2015). Symptomatic cats present non-specific symptoms, for which the most common is weight loss (BURLING et al., 2017; RUDAN et al., 2017). However, some adult cats can develop lymphomas, nonregenerative anemia, myeloproliferative diseases, panleukopenia, and septicemia; some FeLV infected cats can even become infected with other viruses and develop feline infectious peritonitis (FIP) (HARDY JR., 1976). Therefore, it is important to develop new protocols for evaluating the immunological state of these FeLV+ cats. Taking this under consideration, we tested a panel of monoclonal antibodies (MAbs) in peripheral blood of FeLV+ cats, which were concomitantly carrying or affected by other diseases. Our findings showed that anti-B220 MAb can be used to identify a positive cell population (possibly naïve $\mathrm{B}$ cells), which in turn could be an indicator of their immunological status.

We evaluated the amount of B cells (B220+ cells) in FeLV+ cats with different clinical manifestations and positivity by an immunodiffusion test (SNAP FIV/FeLV Combo test, IDEXX Inc., USA) with blood samples harvested by cephalic vein puncture. For this, 26 cats were divided in 5 groups: [1] Control, with FeLV/FIV negative cats ( $n=9)$; [2] Lymphoma, FeLV+ (clinical signs of FeLV and positive SNAP test)/FIV+ cats with lymphoma (confirmed after cytopathologic exam) $(n=4)$; [3] Leukemia, FeLV+ cats with leukemia (confirmed after bone marrow aspiration cytology) $(\mathrm{n}=2)$; [4] "no clinical signs" (NCS), with FeLV/ FIV positive cats without clinical signs of disease until our analysis ( $n=9$ ); and [5] FIP, FeLV/FIP+ cats where FIP were confirmed after necropsies $(n=2)$. The cats used in this study were from the institutional veterinary hospital, from a local pet clinic, and from a local illness-free cattery.

Once collected, red blood cells (RBC) were removed by osmotic shock, using a commercially available RBC lysis buffer (eBioscience Inc., USA), according to manufactory instructions. Cell samples were $2 \mathrm{X}$ centrifuged $\left(390 \mathrm{G}, 5 \mathrm{~min}, 10{ }^{\circ} \mathrm{C}\right)$ and resuspended in a flow cytometry (FACS) buffer (PBS containing 2\% FCS and 0,1\% Sodium Azide) for removal of RBC lysis buffer. Each sample was resuspended in FACS buffer, received $10 \mu \mathrm{L}$ of a FcBlock solution (anti-CD16/32, BD Biosciences Inc., USA, cat. \#14-0161-81, diluted 1:100), and was incubated for $20 \mathrm{~min}, 4{ }^{\circ} \mathrm{C}$, dark chamber. After this, samples were labelled with $10 \mu \mathrm{L}$ of antiCD45R (B220) MAb (BD Biosciences Inc., USA, cat. \# 17-0452-81, 1:100 dilution), for $30 \mathrm{~min}, 4$ ${ }^{\circ} \mathrm{C}$, dark chamber. Next, samples were centrifuged, resuspended in FACS buffer $+1 \%$ Paraformaldehyde, and kept at $4{ }^{\circ} \mathrm{C}$ until acquisition in a FACSCalibur cytometer (DB Biosciences Inc., USA). The following MAbs (DB Biosciences Inc., USA) were tested (1:100) without positive staining: anti-mouse CD4 PerCP (cat. \# 45-0042-82); anti-human CD4 PE (cat. \# 555347), anti-mouse CD25 PE (cat. \# 12-0251-82); anti-mouse Foxp3 PE (cat. \# 12-5773-80); anti-mouse CD8a PE (BD cat. \# 12-0081-83); anti-mouse CD11b APC (cat. \# 17-0112-82); anti-mouse F4/80 PE (cat. \# 12-4801-82); anti-mouse CD19 APC (cat. \# 17-019380); anti-mouse CD3 APC (cat. \# 17-0112-82); antimouse CD11c FITC (cat. \# 11-0114-81).

All data were analyzed with Cell Quest Pro software (BD Biosciences Inc., USA). We presented the variables in terms of mean \pm standard deviation (SD) and results were plot and statistically evaluated in a GraphPad Prism 5.0 Software (GraphPad Software Inc., USA). The differences between groups were tested by ANOVA, followed by pair-wise comparison with Tukey post-hoc test. Significant differences were observed when $\mathrm{P}<0.05$.

Our results showed that anti-mouse B220 antibody was the only one capable of labeling cat leukocytes (Figure 1). When we used it to study the amount of naïve B cell population in cat leukocytes, we observed that the average of this cell proportion in Control cats was $42.6 \%$ (Figure 1), which is similar to the values described by other authors (WILLETT et al., 2007). FeLV+ cats with lymphoma (Lymphoma group) or with no clinical signs (NCS group) had similar levels of B cells as well as control 


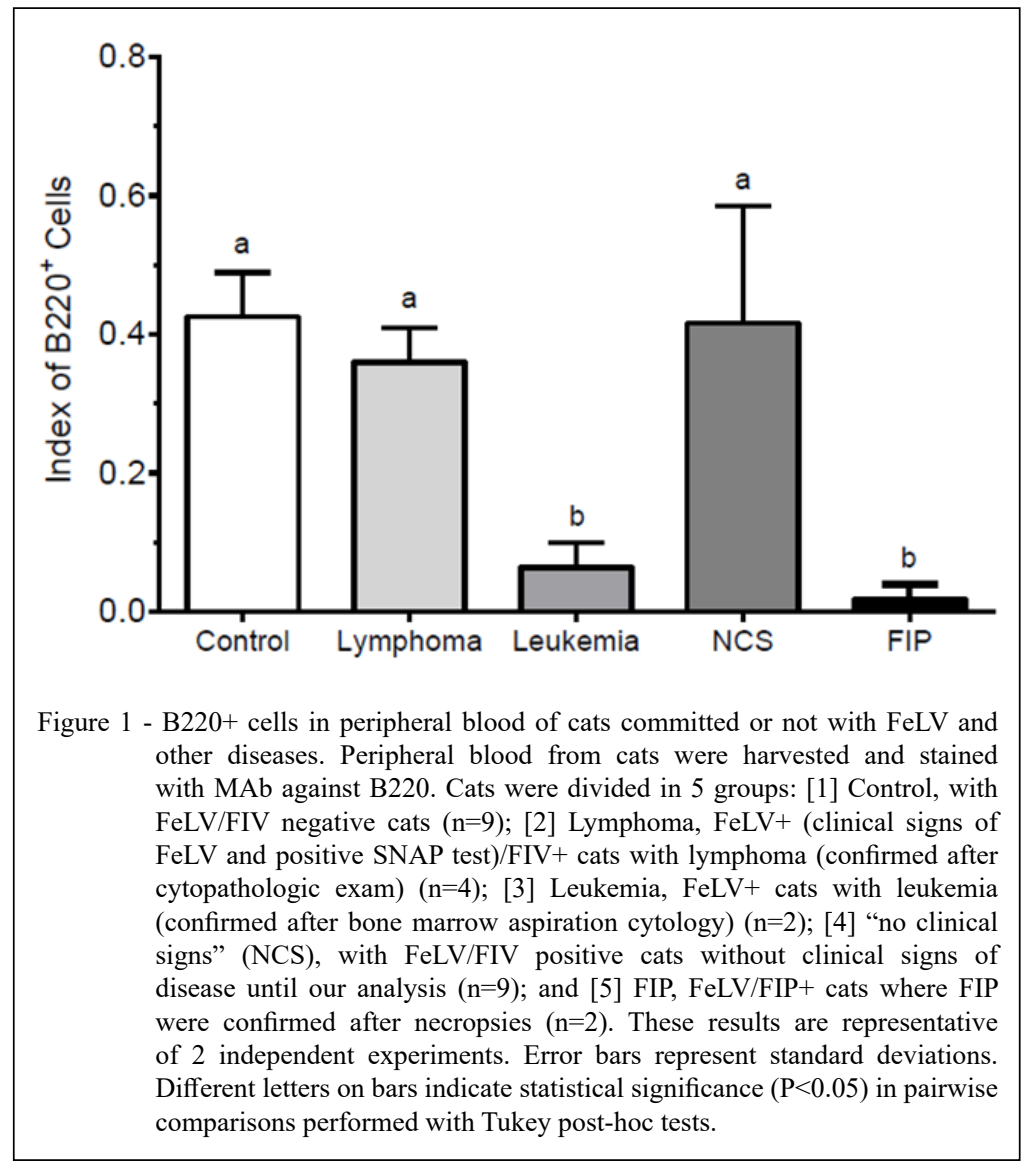

cats. Although, FeLV/FIV+ cats may not seem to represent a high percentage of sick cats in Brazil (BIEZUS et al., 2019; LEITE-FILHO et al., 2019), since our NCS group also gather these FeLV/FIV+ cats with "normal" naïve B cell amounts (Figure 1), it is interesting to know if these cats could active them after an immunization. With respect to the naïve B cell amounts (Figure 1), cats from Leukemia group or form FIP group had fewer B cells than cats from other groups (ANOVA: $\mathrm{F}_{4,22}=8.85, \mathrm{P}<0.001$ ) (Figure 1). In these two cat groups, it is possible that these animals could have a decreased capacity to produce antibodies and compromised humoral immunity against other pathogens. As described before by other authors (PEDERSEN, 2009), FIP infection can lead to a decrease in immune system cells, which can be aggravated by FeLV infection (ANDERSON et al., 1971); in fact, these FIP+ animals died in less than 3 days after being tested, with clinical signs of severe respiratory or intestinal problems. Other recent study has shown that a FeLV/FIP+ cat developed a severe form of toxoplasmosis (ZANDONÀ et al., 2018). In our leukemia + cats, one died a month after testing, and the other was still alive (for 7 months, according to the owner last communication), making it hard to derive any conclusion about their immunological state.

In summary, our results indicated that anti-mouse B220 MAbs can be used to identify a cell population (possibly naïve B cell) in FeLV+ cats, which are concomitantly carrying other debilitating conditions, being an indicator of their immunological status.

\section{ACKNOWLEDGMENTS}

We would like to thank all staff working at Hospital Veterinário UVV - Prof. Ricardo Alexandre Hippler for their help to tracking all FeLV+ patients and Centro de Tecnologia Animal (CTA) for providing all control patients used in this work. We also would like to thank Fundação de Amparo à Pesquisa e Inovação do Espírito Santo (FAPES) for partially supporting this research (grant process \# 100/2019). This work was financed in part by the Coordenação de Aperfeiçoamento de Pessoal de Nível Superior (CAPES), Brasil - Finance code 001.

\section{FUNDING}

This work was partially supported by a FAPES grant (process \# 100/2019) and IDSF received a CAPES PROSUP 
fellowship. This work was financed in part by the Coordenação de Aperfeiçoamento de Pessoal de Nível Superior (CAPES), Brasil Finance code 001 .

\section{BIOETHICS \\ AND \\ BIOSECURITY COMMITTEE APPROVAL}

This study was approved by the Commission of Ethics on the Use of Animals (CEUA-UVV, Brazil, according to Protocol 407/2017.

\section{DECLARATION OF CONFLICT OF INTERESTS}

The authors declare no conflict of interest. The funding sponsors had no role in the design of the study; in the collection, analyses, or interpretation of data; in the writing of the manuscript, and in the decision to publish the results.

\section{AUTHORS' CONTRIBUTIONS}

All authors contributed equally for the conception and writing of the manuscript. All authors critically revised the manuscript and approved of the final version.

\section{REFERENCES}

ANDERSON, L. J, et al. Feline leukemia-virus infection of kittens: Mortality associated with atrophy of the thymus and lymphoid depletion. J. Nat. Can. Inst., v.47, n.4, p.807-817, 1971. Available from: <https://academic.oup.com/jnci/articleabstract/47/4/807/990105> . Accessed: Jul. 25, 2020. doi: 10.1093/ jnci/47.4.807.

BANDECCHI, P, et al. Feline leukaemia virus (FeLV) and feline immunodeficiency virus infections in cats in the Pisa district of Tuscany, and attempts to control FeLV infection in a colony of domestic cats by vaccination. Vet. Record, v.158, n.16, p.555-557, 2006. Available from: $<$ https://veterinaryrecord.bmj.com/content/158/16/555.long $>$. Accessed: Jul. 25, 2020. doi: 10.1136/vr.158.16.555.

BIEZUS, G, et al. Prevalence of and factors associated with feline leukemia virus (FeLV) and feline immunodeficiency virus (FIV) in cats of the state of Santa Catarina, Brazil. Comp. Immunol. Microbiol. Infect. Dis, v.63, p.17-21, 2019. Available from: $<$ https://doi.org/10.1016/j.cimid.2018.12.004>. Accessed: Jul. 25, 2020. doi: 10.1016/j.cimid.2018.12.004.

BURLING, A. N, et al. Seroprevalences of feline leukemia virus and feline immunodeficiency virus infection in cats in the United States and Canada and risk factors for seropositivity. J. Am. Vet. Med. Assoc, v.251, n.2, p.187-194, 2017. Available from: <https:// doi.org/10.2460/javma.251.2.187>. Accessed: Jul. 25, 2020. doi: 10.2460/javma.251.2.187

CRISTO, T. G, et al. Feline Lymphoma and a High Correlation with Feline Leukaemia Virus Infection in Brazil. J. Comp. Pathol, v.166, p.20-28, 2019. Available from: <https://doi.org/10.1016/j. jcpa.2018.10.171>. Accessed: Jul. 25, 2020. doi: 10.1016/j. jсра.2018.10.171.

FIGUEIREDO, A. S.; ARAÚJO JÚNIOR, J. P, Feline leukemia virus: infection outcomes, diagnostic techniques and vaccine efficacy analysis employing sensitive techniques of virus detection. Ciência Rural, v.41, n.11, p.1952-1959, 2011. Available from: <http://dx.doi.org/10.1590/S0103-84782011001100017>. Accessed: Jul. 25, 2020. doi: 10.1590/S0103-84782011001100017.

GROSENBAUGH, D. A, et al. Efficacy of a nonadjuvanted recombinant FeLV vaccine and two inactivated FeLV vaccines when subject to consistent virulent FeLV challenge conditions. Biologicals, v.49, p.76-80, 2017. Available from: <https://doi. org/10.1016/j.biologicals.2016.10.004>. Accessed: Jul. 25, 2020. doi: 10.1016/j.biologicals.2016.10.004.

HARDY JR, W. D, et al. Biology of Feline Leukemia Virus in the Natural Environment Environment. Cancer Res, v.36, n.2, p.582588, 1976. Available from: <https://cancerres.aacrjournals.org/ content/36/2_Part_2/582.long >. Accessed: Jul. 25, 2020.

LEITE-FILHO, R. V, et al. Epidemiological, pathological and immunohistochemical aspects of 125 cases of feline lymphoma in Southern Brazil. Vet. Comp. Oncol, v.18, n.2, 2019. Available from: <https://doi.org/10.1111/vco.12535>. Accessed: Jul. 25, 2020. doi: $10.1111 / \mathrm{vco} .12535$.

LEVY, J. K, et al. Performance of 4 Point-of-Care Screening Tests for Feline Leukemia Virus and Feline Immunodeficiency Virus. J. Vet. Int. Med, v.31, p.521-526, 2017. Available from: <https://doi. org/10.1111/jvim.14648>. Accessed: Jul. 25, 2020. doi: 10.1111/ jvim. 14648 .

MAKUNDI, I, et al. Epidemiologic survey of feline leukemia virus in domestic cats on Tsushima Island, Japan: management strategy for Tsushima leopard cats. J. Vet. Diagn. Invest, v.29, n.6, p.889-895, 2017. Available from: <https://doi. org/10.1177/1040638717725551>. Accessed: Jul. 25, 2020. doi: $10.1177 / 1040638717725551$.

PEDERSEN, N. C, A review of feline infectious peritonitis virus infection: 1963-2008. J. Feline Med. Surg, v.11, n.4, p.225-258, 2009. Available from: <https://doi.org/10.1016/j. jfms.2008.09.008>. Accessed: Jul. 25, 2020. doi: 10.1016/j. jfms.2008.09.008.

RUDAN, N, et al. Evaluation of clinical and haematological parameters in differentiation of feline immunodeficiency and feline leukemia virus infection. Veterinarski Arhiv, v.87, n.6, p.731743, 2017. Available from: $<$ http://wwwi.vef.hr/vetarhiv/index. php?p1 $=$ item $\&$ p $2=2017 \& \mathrm{p} 3=87 \& \mathrm{p} 4=6 \& \mathrm{p} 5=\& \mathrm{p} 6=7>$. Accessed: Jul. 25, 2020. doi: 10.24099/vet.arhiv.160525.

SHAHRANI, F, et al. Molecular study for detection of Feline Leukemia Virus (FeLV) in Iranian cats. African J. Microbiol. Res, v.5, n.15, p.2103-2106, 2011. Available from: <https://academicjournals.org/ journal/AJMR/article-abstract/1B4D23611907>. Accessed: Jul. 25, 2020. doi: 10.5897/AJMR11.294.

STAVISKY, J, et al. Prevalence of and risk factors for FIV and FeLV infection in two shelters in the United Kingdom (20112012). Vet. Record, v.181, n.451, p.1-6, 2017. Available from: $<$ http://dx.doi.org/10.1136/vr.103857>. Accessed: Jul. 25, 2020. doi: $10.1136 /$ vr. 103857 .

TORRESA, A. N, et al. Feline Leukemia Virus Immunity Induced by Whole Inactivated Virus Vaccination. Vet. Immunol. Immunopathol, v.134, p.1-17, 2015. Available from: <https://doi. org/10.1016/j.vetimm.2009.10.017>. Accessed: Jul. 25, 2020. doi: 10.1016/j.vetimm.2009.10.017.

Ciência Rural, v.50, n.12, 2020. 
WILLETT, B. J, et al. Probing the Interaction between Feline Immunodeficiency Virus and $\mathrm{CD} 134$ by Using the Novel Monoclonal Antibody 7D6 and. J. Virol, v.81, n.18, p.9665-9679, 2007. Available from: <https://jvi.asm.org/content/81/18/9665. long>. Accessed: Jul. 25, 2020. doi: 10.1128/JVI.01020-07.
ZANDONÀ, L, et al. Cerebral toxoplasmosis in a cat with feline leukemia and feline infectious peritonitis viral infections. Can. Vet. Journal $=$ La revue veterinaire canadienne, v.59, n.8, p.860 862, 2018. Available from: <https://www.ncbi.nlm.nih.gov/pmc/ articles/PMC6049326/pdf/cvj_08_860.pdf>. Accessed: Jul. 25, 2020. 